\title{
RUMAH TANGGA SEBAGAI SALAH SATU WADAH PENDIDIKAN
}

\author{
Oleh: Musdalifa
}

\begin{abstract}
Family is the first and primary place for children's moral education. A child is born without having any strength except the love of his or her family becomes a resource of life. The children's growth and development is very dependent on other people, particularly his or her parents. The basis of education is given through this environment that goes based on the norms in society. The basis of psychological experiences is taught through mercy and love. The needs about the authority and moral value are integrated into the attitude and behavior as the example of the children's moral development. Considering position of the family that is very important in the children's moral development, the involvement and attention of all parts especially the academic practitioner to comprehensively study in order to become a good reference for the family to lead and develop children's moral education.
\end{abstract}

KEYWORDS: Rumah tangga, pendidikan, keluarga, komunikasi

DEWASA ini hampir semua umat manusia dikejutkan dengan berita-berita melalui media masa, baik cetak maupun elektronik, yang cukup mengerikan dan memprihatinkan. Sejalan dengan perkembangan teknologi yang serba modern, dunia pendidikan pada umumnya - tidak terkecuali dunia pendidikan Islam, khususnya pendidikan keluarga - betul-betul menghadapi tantangan yang cukup signifikan. Maraknya tayangan televisi yang tidak mendidik, pada hampir semua channel, memerlukan pengawasan orangtua agar anak-anak yang berada dalam pengasuhannya tidak menelan mentah-mentah semua informasi yang ditayangkan televisi. Hal ini menjadi harapan semua orang untuk diantisipasi agar bisa berjalan dalam koridor edukatif psikologis.

Dalam konteks pendidikan keluarga diperlukan suatu bimbingan dan konseling yang "luwes dan humanis". Artinya, beberapa prinsip dasar pendidikan keluarga tersebut dilaksanakan berdasarkan komitmen bersama anggota keluarga tersebut. Aturan dalam keluarga yang dirumuskan dalam pola-pola praktis yang "kaku" dikhawatirkan hanya akan mengakumulasi kerawanan masalah. Membiarkan pola seperti ini berkembang pada 
saatnya nanti hanya akan mengancam eksistensi pendidikan keluarga itu sendiri.

Di dalam Alquran maupun hadis Nabi saw. banyak hal yang bisa dicermati dan dikembangkan oleh para pendidik dan orangtua untuk melaksanakan tanggung jawabnya sekaligus mengadakan penelitian yang serius terhadap ayat-ayat Alquran dan hadis-hadis Nabi saw. Di antara ayat Alquran yang berkaitan dengan pendidikan terdapat dalam Q.S. alTahrīm (66): 6, yang artinya sebagai berikut:

Wahai orang-orang yang beriman peliharalah (didiklah) dirimu dan keluargamu dari siksa api neraka yang bahan bakarnya adalah manusia dan batu; penjaganya malaikat-malaikat yang kasar, yang keras, yang tidak mendurhakai Allah terhadap apa yang diperintahkan-Nya kepada mereka dan selalu mengerjakan apa yang diperintahkan. ${ }^{1}$

Kata "didiklah" yang tercantum dalam terjemahan ayat tersebut di atas merupakan tanggung jawab orangtua dan pendidik sekaligus yang cukup besar dan tidak ringan, karena persoalan ini telah dituntut sejak seorang anak dilahirkan hingga ia mencapai usia remaja, bahkan sampai ia masuk usia dewasa yang sempurna. Hal ini telah didesain dalam psikologi sebagai disiplin ilmu yang berbicara mengenai tahapan perkembangan jiwa. Artinya, mendidik anak atau subyek didik diperlukan paradigma berpikir berperspektif psikologi yang metodis, sehingga sesuai dengan target yang diharapkan.

Sedangkan di antara hadis-hadis yang berkenaan dengan pendidikan adalah sebagai berikut:

Didiklah anak-anakmu pada tiga hal: mencintai Nabimu, mencintai ahli bait (keluarga), dan gemar membaca Alquran. ${ }^{2}$

Berangkat dari ayat Alquran dan hadis tersebut di atas setidaktidaknya para pedidik (guru, dosen, dan orangtua) betul-betul menaruh perhatian yang besar terhadap esensi pendidikan dalam keluarga dari generasi ke generasi secara berkesinambungan yang pada intinya untuk menumbuhkembangkan anak pada bingkai akidah, syariah, dan akhlak yang islami dalam suatu keluarga.

\section{KOMUNIKASI DALAM KELUARGA}

Sebagaimana dipaparkan Singgih D. Gunarsa, bahwa akhir-akhir ini hampir semua umat manusia dikejutkan dengan berita-berita melalui media masa, baik cetak maupun elektronik, yang cukup mengerikan dan memprihatinkan yakni "tragedi keluarga". Seorang anggota keluarga yang biasanya menjadi jantung keluarga, bahkan telapak kakinya bisa disama- 
kan dengan surga, karena belum bisa menyelesaikan persoalan-persoalan internal dalam keluarga dan bahkan mungkin karena aspek religi tidak mendasari dalam prinsip hidup berumah tangga, maka sang pendidik utama dan pertama itu mengambil jalan pintas dalam menyelesaikan persoalan hidupnya. Tragedi, cekcok terkait dengan persoalan-persoalan dalam keluarga tersebut setelah diteliti dan dicermati ternyata bermula dari masalah sederhana yaitu ketidaksesuaian antara anggota keluarga. ${ }^{3}$

Ketidaksesuaian terkadang bisa menjadi pangkal penyebab salah paham, pertengkaran, perang dingin antara suami istri bahkan berakibat keruntuhan keluarga. Oleh karena itu, keutuhan keluarga bisa dipelihara dengan memperkokoh ikatan keluarga terutama dengan mengabadikan kesatuan suami istri atau ayah ibu sebagai pemeran utama. Peran ayah-ibu yang telah dibingkai dengan mistaqon gholidzon (akad nikah) dapat diumpamakan sebagai suatu perjalanan yang panjang, penuh kesukaan dan mengasyikkan, apabila jalannya dipersiapkan dengan matang dan lancar. Sebaliknya, perjalanan tersebut bisa membosankan bahkan dapat menimbulkan stres, tekanan batin, dan tekanan psikologis lainnya bila jalanannya dipenuhi dengan setumpuk permasalahan yang rumit. Persiapan ini perlu dipusatkan pada persiapan diri dan perencanaan hidup berkeluarga.

Untuk menyikapi dan mengantisipasi persoalan tersebut di atas, dunia pendidikan Islam sebagai bagian dari peradaban manusia tampaknya tidak lepas dari dampak fenomena ini. Namun, ironisnya, pendidikan Islam dalam menghadapi perkembangan ini tidak menempatkan diri pada posisi strategis dan bahkan cenderung terkungkung dalam posisi yang defensif. Pendidikan Islam seringkali diklaim sebagai sistem pendidikan yang konservatif dan konvensional sehingga umat Islam tidak dapat berharap banyak akan lahirnya nuansa-nuansa dan inovasi-inovasi baru yang menentukan dari pendidikan semacam ini.

Fenomena dunia global saat ini, seperti dianalisis oleh Alvin Toffler, sedang bergerak memasuki gelombang peradaban baru yang disebut dengan gelombang ketiga (the third wave). Gelombang peradaban ini muncul sebagai hasil akselerasi dinamika ilmu pengetahuan dan teknologi modern. Fenomena-fenomena yang ditampilkan dalam panggung gelombang ketiga ini menunjukkan semakin menonjolnya praktek-praktek dehumanisasi. Dalam konteks ini, Toffler memperingatkan untuk mewaspadai munculnya apa yang disebut sebagai future shock (kejutan-kejutan di masa depan) yang berwatak eksesif dan degradatif. 4

Senada dengan apa yang dikemukakan Alvin Toffler, disinyalir pula oleh Singgih D. Gunarsa mengenai solusi beban psikologis antar anggota 
keluarga, terutama suami-istri, ayah-ibu, yaitu diperlukannya komunikasi yang baik dengan membina dan memelihara komunikasi tersebut di dalam keluarga dan dengan masyarakat di luar keluarga, yang meliputi:

1. Membina dan memupuk komunikasi di dalam keluarga. Hubungan antara anggota keluarga harus dipupuk dan dipelihara dengan baik. Hubungan yang baik, kesatuan sikap ayah dan ibu merupakan jalinan yang memberi rasa aman bagi anak-anak. Hubungan serasi ayah-ibu memberi rasa tenang dan keteladanan bagi anak dan keluarga yang kelak dibentuknya.

Anak yang menghadapi kesulitan atau masalah, baik kecil maupun besar mengharapkan tempat bernaung pada orangtua yang bersedia menampung keluh kesahnya, yang hanya dapat diperolehnya melalui komunikasi yang baik. Komunikasi terbentuk bila hubungan timbal balik selalu terjalin antara ayah, ibu, dan anak.

Membina hubungan baik antara suami istri, ayah ibu, membutuhkan waktu yang cukup, suasana yang santai sebagai wadah saling mengungkapkan isi hati, atau berbagi kekesalan yang berkaitan dengan pekerjaan masing-masing, dan keakraban yang menyejukkan.

Kesibukan pekerjaan di luar maupun di dalam rumah sering menyita seluruh waktu dan pikiran ayah ibu, sehingga hampir tidak ada waktu untuk bersantai dan memupuk keakraban. Kadang-kadang terlihat bahwa lebih mudah menjalin hubungan dengan orang lain di luar ikatan keluarga, lebih banyak kesempatan untuk memupuk hubungan dengan teman sejawat daripada dengan anggota keluarga di rumah. Dengan begitu, dalam keluarga justru terdapat jarak atau dinding yang kuat yang tidak bisa diterobos dan berakibat timbulnya persengketaan. Jalinan hubungan dengan orang di luar keluarga justru merupakan hambatan bagi terbentuknya komunikasi dalam keluarga. Membina hubungan akrab bagi suami istri memerlukan tekad yang baik dan derajat toleransi yang tinggi untuk dapat mengatasi beragam masalah.

Hubungan yang dapat mempengaruhi anak kecil pada umumnya mudah terbentuk karena orangtua biasanya merawat dan memelihara anaknya, sehingga banyak waktu bersama anak, kecuali bila sibuk di luar rumah dan ada pengasuh atau penggantinya, maka akan timbul jarak antara orangtua dengan anak. Sebab, anak akan lebih banyak berkomunikasi dengan pengasuh. Orangtua kehilangan kesempatan untuk meletakkan dasar pegangan hidup kepada anaknya. Sulit juga bagi anak untuk menjadikan orangtua sebagai model pola tingkah laku. Keinginan anak tidak dipenuhi oleh orangtua, melainkan oleh pengasuh. Kalau keinginan orangtua tidak dijalankan oleh anak, maka 
timbul ketidakpuasan, yang kadang-kadang disalurkan dalam bentuk perilaku agresif. Kendala komunikasi orangtua dan remaja berpangkal pada masalah waktu.

Orangtua mengalami dan menjalani waktu remaja yang berbeda dengan anak-anaknya. Keinginan anak remaja menurut penilaian orangtua belum waktunya dipenuhi. Sebaliknya rencana orangtua bagi anak remaja selalu ditangguhkan oleh anak remaja, sehingga sulit mencapai kesesuaian antara orangtua dan anak remaja. Hubungan timbal balik antara sesama anak juga harus dibina dan dipelihara. Setiap anak lahir dengan potensi yang berbeda dengan anak lainnya. Bekal potensi yang berbeda menyebabkan keberhasilan dan prestasi, misalnya, di sekolah juga tidak sama. Yang kurang berprestasi sering mendapat teguran, sering diberi saran agar tidak mengambil contoh kakak atau adik, yang lebih berhasil. Ada anak yang merasa diistemawakan, disayang, diberi tugas khusus sebagai harapan keluarga. Pandangan anak mengenai tempatnya dalam keluarga menyebabkan hubungan antar anak tidak selalu serasi. Setiap anak ingin memiliki tempat di hati orangtua, karena ia memiliki sesuatu yang khas yang ada pada dirinya, bukan dibandingkan dengan anak lain. Lebih-lebih bila membandingkan dengan anak di luar ikatan keluarga atau bukan saudara kandung, tetapi saudara tiri, maka persaingan antar anak akan bertambah kuat, sampai terasa persaingan-persaingan yang menghambat terjalinnya hubungan yang baik antara sesama anak.

Agar setiap anggota keluarga tidak terombang-ambing, dan bisa merasa aman dan damai dalam keluarga, perlu ada hubungan serasi antara suami istri, perlu kesatuan, keseragaman sistem dan sikap penilaian ayah ibu terhadap tindak tanduk anak. Kesinambungan anak dalam komunikasi dengan orangtua dan tata cara hidup yang baik memberi rasa aman pada anak dalam keteraturan keluarga.

2. Hubungan baik dalam keluarga bisa dibina dan dibentuk apabila setiap anggota keluarga memiliki pegangan hidup yang teguh, iman yang kuat yang dilandasi oleh petunjuk, yakni berupa norma-norma yang sudah mendarah daging. Pegangan hidup ini diperoleh melalui internalisasi berbagai norma agama yang menjadi pedoman hidup. Suasana harmonis dan lancarnya komunikasi dalam keluarga dapat mengantarkan anggota keluarga lainnya menyadari dan menjalankan tugas serta kewajiban masing-masing sambil menikmati haknya sebagai anggota keluarga. Dalam usaha mendidik dan membentuk kepribadian anak, internalisasi berbagai firman Allah, harus dimulai sedini mungkin, sebagai petunjuk dan pedoman hidup sehari-hari. Agar komunikasi 
atau hubungan timbal balik dapat terpelihara dengan baik, maka hubungan timbal balik dalam keluarga hendaknya dibangun dalam kaitan yang kuat, dengan prinsip sebagai berikut:

Hubungan suami istri berdasarkan kasih dan cinta

Hubungan orangtua dengan anak didasarkan kasih sayang

Hubungan orangtua dengan anak remaja berdasarkan kasih sabar

Hubungan antara anak didasarkan atas kasih sesama

\section{PENTINGNYA STABILITAS KELUARGA}

Dalam uraian yang lalu dijelaskan bahwa keluarga merupakan dasar utama pembentukan kepribadian manusia, keluargalah yang memberi arah dan corak serta pandangan hidup yang akan dialami anak pada masa selanjutnya. Oleh karena itu, keluarga perlu menjaga stabilitas, ketenangan, dan ketenteraman di antara semua anggota keluarga terutama suami isteri sebagai pengendali dan penanggung jawab dalam keluarga.

Farid Ma'ruf Noor dalam Rahman Getteng mengatakan, kesejahteraan dan kebahagiaan rumah tangga atau keluarga merupakan satu dasar untuk meletakkan pembangunan kehidupan suatu masyarakat dan negara yang sejahtera dan bahagia sebagai inti kehidupan masyarakat yang terkecil dan eselon masyarakat terbawah yang akan menentukan bentuk, corak, warna, dan situasi kehidupan masyarakat dan negara di mana rumah tangga itu berada.

Di dalam ajaran Islam terdapat enam faktor yang menjadi dasar pembangunan rumah tangga yang stabil, bahagia, dan sejahtera sebagai berikut:

1. Suami istri mempunyai niat yang ikhlas dalam membangun rumah tangganya;

2. Setiap anggota keluarga atau rumah tangga memahami dan dapat menjalankan fungsinya masing-masing;

3. Terciptanya suasana keagamaan dalam kehidupan rumah tangga seharihari;

4. Terpelihara kesehatan hidup;

5. Terpenuhinya kebutuhan ekonomi keluarga;

6. Tercapainya fungsi pendidikan keluarga terutama bagi anak-anak. ${ }^{5}$

Setiap orang yang sudah berkeluarga bercita-cita dan berkeinginan agar keluarganya senantiasa rukun, aman, penuh dengan ketenangan dan kebahagiaan yang dilandasi dengan rasa kasih mengasihi serta cinta mencintai di antara semua anggota keluarga terutama antara suami isteri. Seringnya terjadi komplikasi atau kontra antara suami isteri dalam suatu 
keluarga akan berakibat fatal bagi anak-anak. Sebab, sebagaimana diketahui bahwa dalam rumah tangga terdapat variasi yang bermacam-macam, yang berpangkal pada perasaan dan keinginan serta kebutuhan berbeda di antara kedua belah pihak dalam kehidupannya sehari-hari. Apalagi jika ada hal-hal yang tidak diungkapkan dengan kata atau perbuatan, tetapi hanya dibisikkan dengan perasaan yang halus dalam hati nurani masingmasing.

Dari perasaan, keinginan, dan kebutuhan yang berlainan inilah yang seringkali menjadi faktor dasar yang dapat menimbulkan konflik yang pada akhirnya mengakibatkan perselisihan dalam rumah tangga yang sulit diatasi. Ramayulis dan kawan-kawan mengutip pendapat Gary Alexander, seorang berkebangsaan Amerika, yang banyak menyoroti masalah perselisihan dalam rumah tangga, membuat resep "Five Ways to Save Your Marriage" yang diringkas oleh Ramayulis sebagai berikut:

1. Kelangsungan untuk memahami hubungan timbal balik antara suami isteri terutama kepekaan memahami hal-hal yang tidak terungkapkan;

2. Kesanggupan membangun dan menciptakan keserasian hidup berumah tangga;

3. Kesanggupan untuk saling memberikan keharmonisan dan kepuasan dalam hubungan seks;

4. Kesanggupan untuk saling memahami peranan masing-masing;

5. Kesanggupan untuk mematuhi kesepakatan dalam mengatur pembiayaan rumah tangga dan hal-hal yang berhubungan dengan masalah itu. ${ }^{6}$

Ketenangan, kebahagiaan, dan kesejahteraan merupakan pangkal dan ujung kehidupan berkeluarga. Semua itu dapat dicapai bila senantiasa berpijak kepada petunjuk yang digariskan oleh Islam dan meneladani Sunnah Rasulullah saw. ${ }^{7}$

Ajaran Islam sangat mengantisipasi agar kehidupan dalam keluarga senantiasa diliputi oleh ketenangan dan kebahagiaan, dilandasi dengan rasa cinta dan kasih sayang (mawaddah wa rahmah), saling pengertian, dan tahu hak dan kewajibannya, sehingga tercipta suhu yang aman dan tenteram untuk menjamin terciptanya kestabilan dalam keluarga secara terus menerus.

Kestabilan dalam hidup berkeluarga sangat penting artinya mengingat pembinaan mental anak sangat tergantung dari kehidupan keluarganya (orangtua), perselisihan dan konflik yang sering terjadi di dalam rumah tangga (ayah-ibu) akan mengakibatkan penyimpangan bagi anak, setiap kali membuka mata si anak yang terlihat adalah permusuhan, maka anak akan berusaha menjauh dari rumah orangtuanya untuk bergaul dengan orang lain. ${ }^{8}$ 
Ajaran Islam memberikan tuntunan agar orangtua (ayah dan ibu) sebagai penanggung jawab dalam rumah tangga dapat bergaul dengan sebaik-baiknya dengan semua anggota keluarga. Sebab sebagaimana diketahui bahwa dalam keluarga yang unsur-unsurnya terdiri dari ayah, ibu, dan anak-anak perlu menjalin keharmonisan teristimewa bagi ayah dan ibu karena kepada merekalah tercermin tindak tanduk dan perbuatan yang dapat menjadi contoh teladan atau uswatun hasanah bagi anakanaknya maupun orang lain.

Alquran dan Sunnah Rasulullah saw. telah memberikan tuntunan untuk menjamin kelangsungan hidup rumah tangga dan menciptakan keluarga yang harmonis. Hal ini antara lain dijelaskan dalam Q.S. al-Nisā' (4): 19, yang berbunyi:

\section{四囲}

\section{.}

...Dan bergaullah dengan mereka secara patut. Kemudian bila kamu tidak menyukai mereka, (maka bersabarlah) karena mungkin kamu tidak menyukai sesuatu, padahal Allah menjadikan padanya kebaikan yang banyak. ${ }^{9}$

Ayat tersebut di atas memberi pelajaran, terutama kepada suami selaku pemimpin dalam rumah tangga, agar dapat bergaul dengan isteri dan anggota keluarganya dengan sebaik-baiknya. Dalam hal ini seorang suami dituntut agar mampu bermuka manis dan penuh kasih sayang serta memberikan nasehat dengan cara yang sebaik-baiknya apabila salah seorang di antara keluarganya berbuat keliru, karena kelemahlembutan dalam rumah tangga merupakan salah satu ciri sebagai seorang mukmin yang sempurna, seperti yang dijelaskan oleh Rasulullah saw. dalam salah satu sabdanya yang berbunyi:

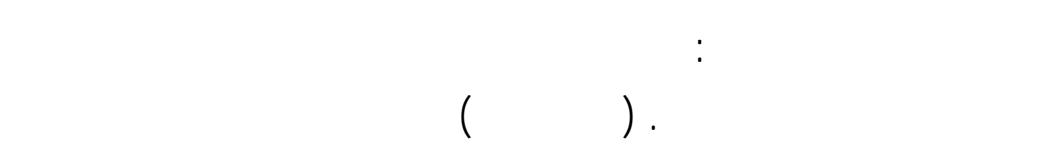

Dari Abu Huraerah ra. berkata: Rasulullah saw. telah bersabda: Mukmin yang paling sempurna keimanannya ialah mereka yang paling baik akhlaknya dan yang terbaik di antara kamu ialah yang paling baik kepada isterinya. ${ }^{10}$

Dengan begitu, untuk menjaga stabilitas keluarga sesuai yang didambakan diperlukan tanggung jawab dan dedikasi yang tinggi antara suami iteri, ta'äwun dan ta'âthuf atau tolong menolong dan ramah tamah serta lemah lembut antara satu dengan yang lain, sebab hanya dengan sikap seperti itu akan tercapai kehidupan yang sakinah atau ketenangan 
yang dilandasi dengan mawaddah dan rahmah atau cinta kasih sayang, seperti yang dijelaskan dalam Q.S. al-Rūm (30): 21, yang berbunyi:

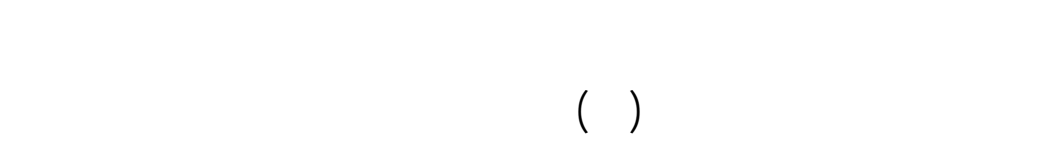

Dan di antara tanda-tanda kekuasaan-Nya ialah Dia menciptakan untukmu isteri-isteri dari jenismu sendiri, supaya kamu cenderung dan merasa tenteram kepadanya, dan dijadikan-Nya di antaramu rasa kasih dan sayang. Sesungguhnya pada yang demikian itu benar-benar terdapat tanda-tanda bagi kaum yang berfikir. ${ }^{11}$

Ahmad Mustafa al-Maragi menjelaskan maksud ayat tersebut dengan mengatakan bahwa: "Dan di antara tanda-tanda kekuasaan-Nya yang menunjukkan adanya hari berbangkit ialah Dia menjadikan bagimu isteriisteri dari jenismu sendiri supaya kamu merasa senang kepadanya. Dan Dia menciptakan di antara kamu rasa cinta kasih sayang supaya kehidupan berumah tangga tetap stabil." 12

Rumah tangga yang stabil sebagaimana yang dijelaskan di atas, dapatlah dipahami bahwa keluarga yang stabil tidak mutlak penghuninya tidak pernah mengalami bentrokan setidak-tidaknya bentrokan perasaan selama mereka membina rumah tangga. Dalam hubungan ini H.S.M. Nasaruddin Latief, menegaskan:

Adanya bentrokan-bentrokan perasaan yang timbul sekali-sekali, lebih-lebih dalam periode masa penyesuaian diri satu terhadap lainnya, tidak perlu diartikan bahwa mereka tidak/kurang bahagia. Adanya kadang-kadang perasaan "kurang enak" di pihak suami atau di pihak isteri, boleh dianggap sebagai rempah-rempah dan asam garamnya kehidupan. ${ }^{13}$

Hanya saja bentrokan-bentrokan tersebut harus ditekan sekecil mungkin, karena apabila terjadi bentrokan yang mewarnai kehidupan keluarga, maka ia dapat diibaratkan sebagai bunga-bunga api yang sewaktu-waktu dapat menghapuskan kehidupan keluarga.

Uraian di atas memberikan indikasi bahwa yang dimakud dengan pentingnya stabilitas keluarga adalah menjaga agar dalam kehidupan keluarga (rumah tangga) tidak diwarnai oleh bentrokan-bentrokan yang pada akhirnya dapat mengakibatkan keretakan. Sebab, yang demikian itu dapat mempengaruhi ketenangan dan ketenteraman baik di pihak suami maupun di pihak isteri. Bahkan, lebih dari itu, yang lebih parah lagi jika bentrokan-bentrokan itu terjadi di hadapan anak, maka akan dapat mempengaruhi pertumbuhan dan perkembangan jiwa anak-anaknya di kemudian hari. 
Perlakuan dan keadaan sebagaimana yang dikemukakan di atas, akan berakibat fatal bagi anak karena dapat menimbulkan rasa ragu dan bimbang dalam jiwa anak, sehingga anak bisa jadi frustasi menghadapi kenyataan yang dialami dalam keluarganya. Di sinilah pentingnya menjaga stabilitas keluarga karena akibatnya bukan saja terhadap suami isteri sebagai sasarannya, tetapi terhadap anak-anaknya sebagai generasi masa depan.

\section{PENUTUP}

Berdasarkan uraian di atas, maka dapat ditarik beberapa kesimpulan sebagai berikut:

1. Keluarga merupakan unit terkecil dalam masyarakat, ia merupakan pondasi tegaknya suatu masyarakat dan bangsa, masyarakat dan bangsa akan kokoh dan kuat bila dimulai dari kehidupan keluarga yang kokoh pula. Oleh karena itu, orangtua mempunyai peranan yang sangat besar dalam usaha membina dan menciptakan kestabilan keluarga, di antaranya dengan cara memupuk cinta dan kasih sayang, tahu hak dan kewajiban di antara semua anggota keluarga dan sebagainya.

2. Keluarga merupakan wadah pertama dan utama pembinaan pendidikan anak, karena itu perlu menciptakan kestabilan dan keharmonisan dalam rumah tangga (keluarga). Dengan begitu, dapat tercermin tindak tanduk dan perbuatan yang dapat menjadi contoh teladan atau uswatun hasanah bagi anak-anaknya maupun orang lain.

3. Kestabilan keluarga mempunyai pengaruh yang sangat besar terhadap pertumbuhan dan perkembangan anak, karena kestabilan keluarga akan membawa anak merasa tenang dan tenteram, tetapi bila dalam kehidupan keluarga tidak stabil, anak akan merasa tidak tenang dan bimbang menghadapi kenyataan hidup.

4. Pembinaan keluarga sejahtera dan stabil bukanlah suatu hal yang mudah, sebab ada faktor-faktor yang mempengaruhinya. Faktor-faktor itu adalah kecukupan sandang, pangan, dan papan. Faktor lainnya adalah tersedianya sarana kesehatan, pendidikan, lapangan kerja, sarana rekreasi, keamanan dan kesempatan penuh untuk beribadah. Pemenuhan kebutuhan dasar tersebut mutlak diperlukan agar bahtera kehidupan dalam keluarga dapat berjalan dengan baik dan stabil.

5. Keluarga yang stabil dan sejahtera yang didambakan dapat terwujud apabila seluruh anggota keluarga dapat menghayati dan mengamalkan ajaran Islam dalam segala aspek kehidupannya serta masing-masing memahami fungsi dan tugas masing-masing serta tanggung jawab pembinaan keluarga. 
6. Usaha untuk menciptakan keluarga stabil dan harmonis dapat ditempuh dengan jalan mempermantap akidah, gemar melaksanakan ibadah, amal saleh serta akhlak mulia, sehingga kehidupan sehari-hari selalu diwarnai semangat hidup yang penuh dengan rasa persaudaraan, persamaan, dan saling hormat menghormati, gotong royong, bahu membahu untuk kepentingan bersama.

\section{CATATAN AKHIR}

1. Zaini Dahlan, Qur'an dan Terjemahan Artinya, Yogyakarta: UII Press, 1998, h. 1020.

2. Abdullah Nasih Ulwan, Psikologi Umum dan Sosial, 1999, h. 195.

3. Singgih D. Gunarso, Psikologi Umum dan Sosial, 1991, h. 195.

4. Yusuf Amir Feisal, Reorientasi Pendidikan Islam, Jakarta; Gema Insani Press, 1995.

5. Lihat Rahman Getteng, Pendidikan Islam dalam Pembangunan, Yayasan AlAhkam Ujung Pandang, 1997, h. 77.

6. Ramayulis dkk., Pendidikan Islam dalam Rumah Tangga, cet. II, Jakarta: Kalam Mulia, 1990, h. 47-48.

7. Disadur dari Mahmus al-Shabbagh, Al-Sa'aadah al-Jawjiyah fi al-Islam, diterjemahkan oleh Bahruddin Fannani dengan judul Tuntunan Keluarga Bahagia Menurut Islam, cet. I, Bandung: PT. Remaja Rosdakarya, 1991, h. 120.

8. Lihat Abdullah Nashih Ulwan, Tarbiyat al-Aulaad fi al-Islam, diterjemahkan oleh Khalilullah Amhas Masykur Hakim dengan judul: Pendidikan Anak Menurut Islam Pemeliharaan Kesehatan Jiwa Anak, cet. I, Bandung: PT. Remaja Rosdakarya, 1990, h. 98.

9. Departemen Agama R.I., Al-Qur'an dan Terjemahannya, Proyek Pengadaan Kitab Suci Al-Qur'an, Jakarta, Sirajaya Santra, 1986/1987, h. 119.

10. Abi Zakaria bin Syarat Yahya, An-Nah Riyathushshalihin, cet. I, Mesir: Mustafa al-Baby al-Halaby Wa Auladuhu, 1357 H/1939 M., h. 151.

11. Departemen Agama R.I., Al-Qur'an dan Terjemahannya, h. 644.

12. Ahmad Mustafa al-Maragi, Tafsir al-Maragi, juz XXI, Qairo: Mustafa al-Bab alHalabi, 1963, h. 37.

13. H.S.M. Nasaruddin Latief, Keluarga Muslim, Jakarta: BP-4 Pusat, 1971, h. 18-19.

\section{DAFTAR PUSTAKA}

Dahlan, Zaini, Qur'an dan Terjemahan Artinya, Yogyakarta: UII Press, 1998.

Departemen Agama R.I., Al-Qur'an dan Terjemahannya, Proyek Pengadaan Kitab Suci Al-Qur'an, Jakarta, Sirajaya Santra, 1986/1987.

Feisal, Yusuf Amir, Reorientasi Pendidikan Islam, Jakarta; Gema Insani Press, 1995.

Getteng, Rahman, Pendidikan Islam dalam Pembangunan, Yayasan Al-Ahkam Ujung Pandang, 1997.

Gunarso, Singgih D., Psikologi Umum dan Sosial, 1991. 
Latief, H.S.M. Nasaruddin, Keluarga Muslim, Jakarta: BP-4 Pusat, 1971.

Al-Maragi, Ahmad Mustafa, Tafsir al-Maragi, juz XXI, Qairo: Mustafa al-Bab alHalabi, 1963.

Ramayulis dkk., Pendidikan Islam dalam Rumah Tangga, cet. II, Jakarta: Kalam Mulia, 1990.

Al-Shabbagh, Mahmus, Al-Sa'aadah al-Jawjiyah fi al-Islam, diterjemahkan oleh Bahruddin Fannani dengan judul Tuntunan Keluarga Bahagia Menurut Islam, cet. I, Bandung: PT. Remaja Rosdakarya, 1991.

Ulwan, Abdullah Nashih, Tarbiyat al-Aulaad fi al-Islam, diterjemahkan oleh Khalilullah Amhas Masykur Hakim dengan judul: Pendidikan Anak Menurut Islam Pemeliharaan Kesehatan Jiwa Anak, cet. I, Bandung: PT. Remaja Rosdakarya, 1990.

Ulwan, Abdullah Nasih, Psikologi Umum dan Sosial, 1999.

Yahya, Abi Zakaria bin Syarat, An-Nah Riyathushshalihin, cet. I, Mesir: Mustafa alBaby al-Halaby Wa Auladuhu, 1357 H/1939 M. 